\title{
The Effect of Macroeconomic Factors and Political Events on the Performance of Nairobi Securities Exchange in Kenya
}

\author{
Dominic Ntabo Amoro, (PhD Student) \\ University of Nairobi, School of Economics, Kenya
}

\begin{abstract}
Stock market plays a significant positive role in the development of the capital market. Political events and changes in macroeconomic variables have been suspected to have an effect on the trading volume and stock return. Thus, this paper focuses on analyzing how macroeconomic factors and political events affect the performance of NSE in Kenya covering the period from January 2000 to February 2019. This was performed using inflation, exchange rate, money supply, 91-Day Treasury bill, and political events represented using dummy variables. The study uses secondary data, and the sources of the data include Capital Markets Authority quarterly bulletins and the Central Bank of Kenya statistics.

ARDL Error Correction model was used to estimate the extent to which macroeconomic factors and political events affect the performance of NSE in Kenya. This is because some of the variables are stationary and others are nonstationary. The results show that exchange rate, money supply, 91-Day Treasury bill, and political events were statistically significant except for inflation which is not statistically significant.

Therefore, a joint effort from individuals, stakeholders, economists, investors, and government is required to secure the effectiveness of the financial market in Kenya since financial markets are dynamic. They are also affected by various macroeconomic factors and some political instability incidents over the recent past like the 2007/2008 post-election violence. The result of the study may encourage and motivate the investors and policy makers both domestically and internationally to make vital strategic decisions.
\end{abstract}

Keywords: Nairobi Securities Exchange (NSE), Macroeconomic factors, political events, Kenya 


\section{Introduction}

Stock markets are economic institutions which enhance the efficiency in capital formation and allocation (Olweny \& Kimani, 2011). The stock market acts as a barometer in an economy in that it provides vital information on the future of the economy as it reflects how an economy performs (Srivastava, 2010). Both developing and developed countries have formed stock exchange markets to help in raising long term capital for firms that are allowed to subscribe to shares and stocks. It therefore assists in channeling funds from savings to investments (Mohammad, Hussain \& Ali, 2009). Volatilities in macroeconomic factors in an economy cause firms or market participants to increase or decrease trading activities. Stock market is therefore important as it acts as a mediator between borrowers and savers. In addition, it is through stock market operations that both borrowers and lenders preferences are harmonised.

The performance of stock market reflects on an institutional framework as well as political environment, and it is influenced by the nature of current economic situation which is reflected by variations in macroeconomic variables like Treasury bill, money supply, inflation rate, and exchange rate in the economy (Wawire, Kirui \& Onono, 2014). Stock market's correlation with the domestic and global stability of a country is strong. However, the unsound financial standings and national and global uncertainty have a significant effect on the stock market exchange performance in a country (Khan, Saif \& Rehman, 2013).

Kenya is an emerging economy and therefore its economic performance is often pegged on a number of parameters, which include but not limited to: the performance of the stock markets, foreign direct investment, inflation rates, and interest rates. These parameters are affected majorly by the political stability/instability, which is equally affected by the electoral process in the country as most electoral processes and outcomes in developing countries are marred with a lot of uncertainties which affect investors' attitudes (Wawire et al., 2014).

Political events play a vital role in explaining stock market performance variations and the degree of uncertainty in the stock market (Tzachi, 2003). For instance, during election periods, politicians soothe investors and firms to fund their political affiliations (Worthington, 2006). Therefore, variations in prices in the stock market reflect the electoral prospects of parties competing (Bechtel \& Fuss, 2006). Market participants expect positive stock market performance following a new regime in office. Market participants and scholars are still analyzing the effect of political change in the stock market whether or not it has an effect on the stock market performance (Chuang \& Wang, 2009). 
Political events may affect stock price either positively or negatively depending on the intensity of the event (Malik, Hussain \& Ahmed, 2009). Major political events that we expect to affect the behaviour of investors both local and foreign include: the general elections 2002, 2007 and 2013, the postelection violence in the first quarter of 2008 and referenda like the one of 2005 and 2010 as well as Nubian-Luo 2001 crisis in Kibera. However, the political economy of a country can result to a significant influence on consumption by individuals and income distribution, hence affecting the activities in the stock market (Menge, Mwangi \& Kimani, 2014).

Financial markets consist of money markets and capital markets. Financial markets facilitate trading, hedging, diversification, and pooling of risks (Levine, 1997). However, the role of financial markets in developing countries has been constrained by the fact that majority of them are in their earlier stages of development. These developing markets have a low number of listed companies and low capitalization among market participants (Yartey \& Adjasi, 2007). The financial sector comprises of commercial banks, investment banks, insurance, microfinance banks, non-bank financial institutions, and securities companies. Hence, the banking sector play an important role in financial intermediation.

Trend Analysis of some Economic Variables

Figure 1. A graph showing the trend for NSE 20-share index from 2000 to 2018

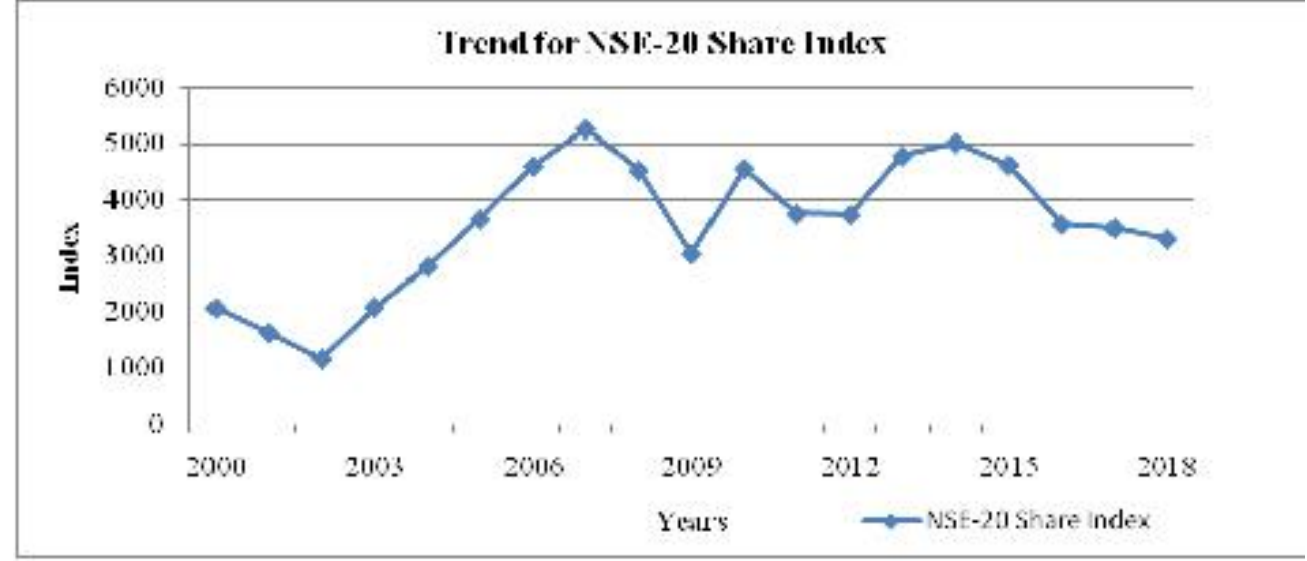

Source: Researcher's analysis based on data from CMA quarterly bulletin

From Figure 1, the NSE 20-share index declined from the year 2000 until the election year 2002 after which it showed an upward trend until 2006. From the year 2007 to December 2008, the index decreased. The index fell in 2009 as investors focused their portfolio on the bond market (Mwega, 2010). In the year 2011, there was a decline until the start of year 2012 when there 
was an increase again until the year 2014. After that, it declined to the year 2018

Figure 2. Graph showing the trend for Inflation rate from 2000 to 2018

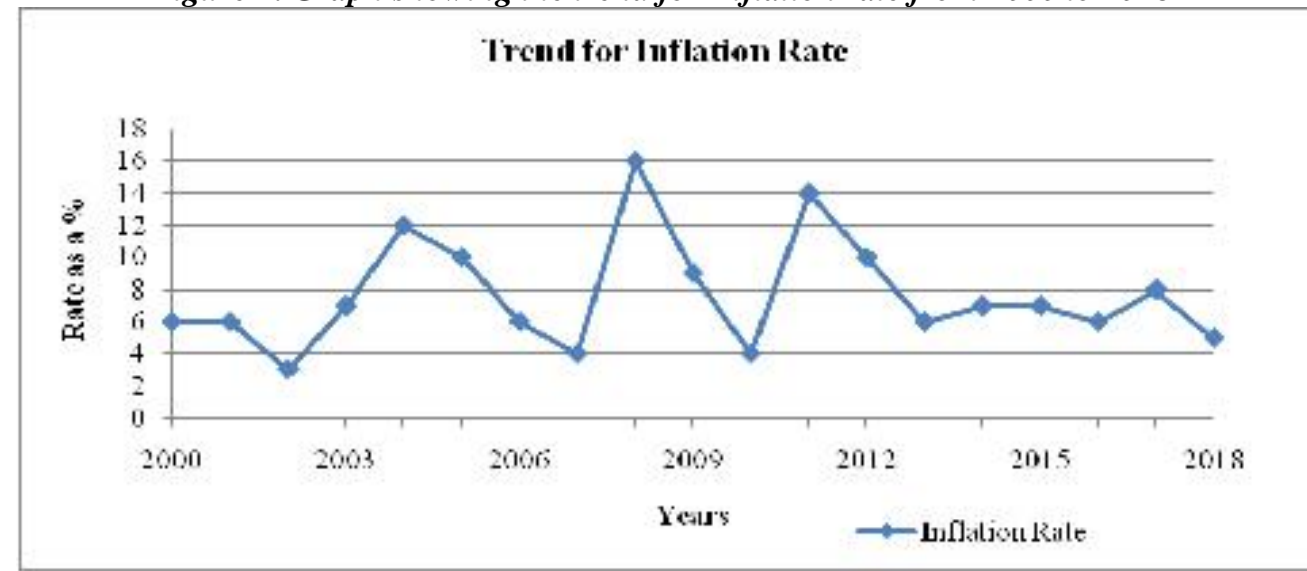

Source: Researcher's analysis based on data from Central Bank monthly statistical bulletins.

From Figure 2, inflation rate has been fluctuating over the years. For instance it increased from 2001 to 2004, decreased to 2005, and increased tremendously from 2007 to 2008 because of the post-election violence and political crisis which have destabilized the economy (Koech \& Rotich, 2013). From 2008, it declined until 2010 when inflation was under control by Central Bank of Kenya. In 2011, inflation was high as it was fuelled by drought in 2010 which led to high prices for stable food like maize (Were \& Tiriongo, 2012). In the year 2012, it declined as it was controlled by Central Bank. It rose again from 2013 to 2014, declined in 2015 and rose slightly in 2016, and declined in 2017 and 2018.

Figure 3. Graph showing the trend for Exchange rate from 2000 to 2018.

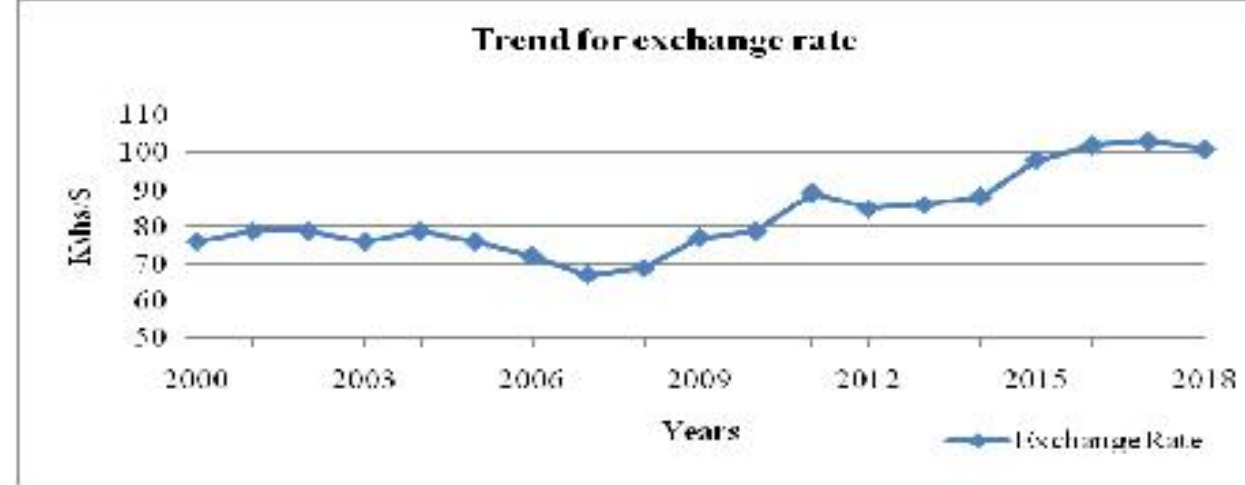

Source: Researcher's analysis based on data from Central Bank monthly statistical bulletins.

From Figure 3, the exchange rate has been almost stable between Kshs 70 to 80 per US\$1 since the year 2000 to 2006. In 2007, it appreciated in value 
as it was below Kshs 70/\$. From 2008, it started depreciating until 2011 rising till the year 2011. At this point, the Kenyan currency depreciated to almost Kshs 90 for one dollar and it later declined mid 80s after the intervention of monetary authorities who explored every avenue to tame the exchange rate volatility (Were \& Tiriongo, 2012). From 2015 to 2017, it increased steadily making the currency to lose value but declined slightly in 2018.

Figure 4. Graph showing the trend for Money Supply from $2000-2018$

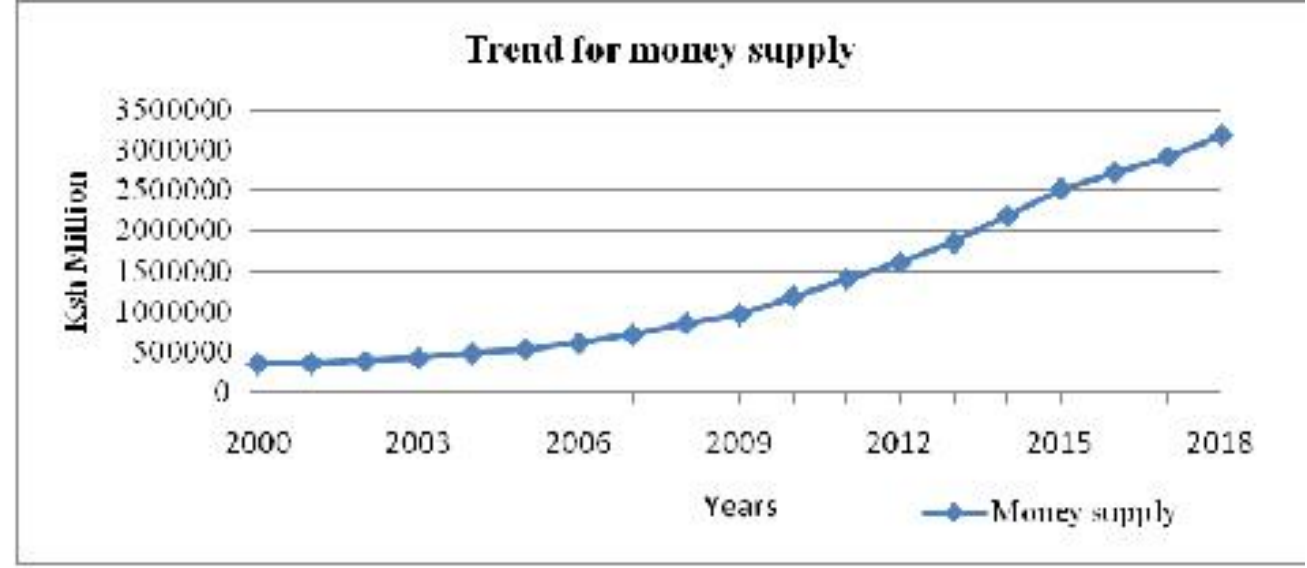

Source: Researcher's analysis based on data from Central Bank monthly statistical bulletins.

The trend for money supply in Figure 4 depicts continuous increase in money supply from the year 2000 to 2018, surpassing Ksh 2 trillion in 2014.

Figure 5. Graph showing the trend for 91-Day Treasury bill from 2000 to 2018

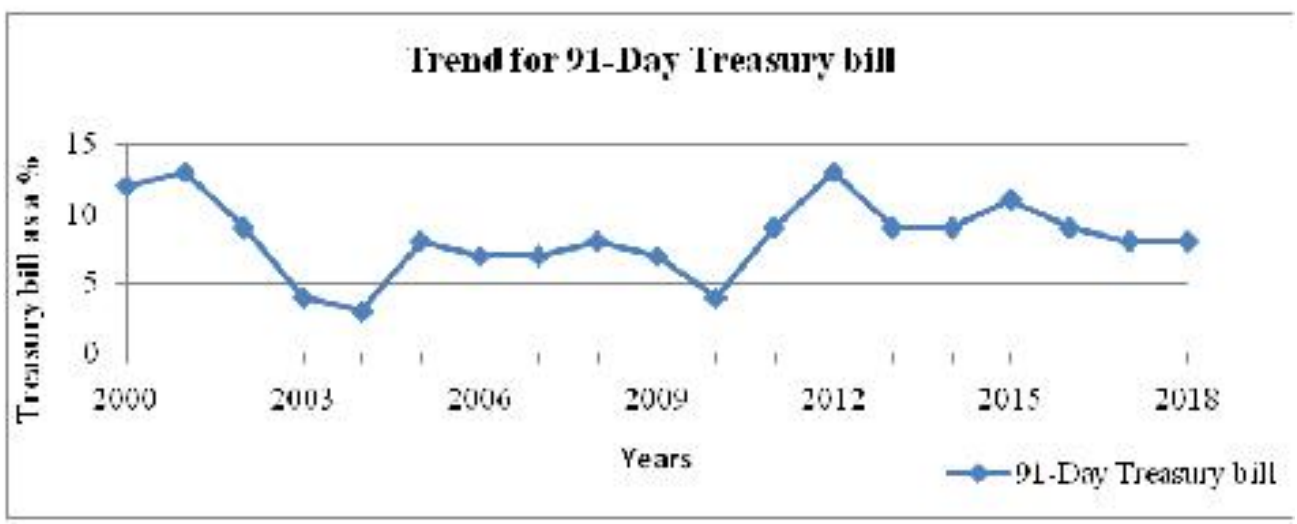

Source: Researcher's analysis based on data from Central Bank monthly statistical bulletins.

Figure 5 show that 91-Day Treasury bill rate has been fluctuating over the years. From 2000, the 91-Day Treasury bill declined from the year 2000 until 2004 where it increased for a short period. In 2005, the rate maintained between $5-10 \%$ until 2009. It declined again to 2010 before it increased 
tremendously in 2011. At this point, the rates were attractive to investors as the Kenyan government sold the Treasury bills at a higher rate to control money in circulation caused by too much remittance into the country as a result of currency depreciation. It later declined when the currency menace was under control.

Consequently, the above macroeconomic variables show that the variables and performance of stock market is close as global financial markets become liberalized. These variables are significant in determining stock market performance as they reflect the macroeconomic state which enables investors to make a decision to invest (Junkin, 2012).

\section{I.}

\section{Problem Statement}

Stock market contributes to the economic development of a country through boosting savings (Junkin, 2012). In addition, stock market creates an environment conducive for business transactions. Volatile market makes investors lose confidence and makes them afraid to invest in stock market. Consequently, this has a negative impact on the economy.

Many studies that have been done are based on developed markets evaluating stock returns, volatility, and macroeconomic variables (Alshogeathri, 2011). Thus, technocrats would wish to find out the variables they need to keep check in ensuring a conducive environment is created for investment in stock markets. Therefore, an in-depth relationship need be established between the macroeconomic variables and political events on the performance of stock market.

Various political events are known to significantly influence stock market. Some researchers have identified elections as the only political event. However, in this study, we explored more political events in Kenya which is a major variable in determining stock market performance. This study gives a different dimension on how the political event is measured to provide empirical evidence on its effect on stock market performance. Since political events is an influential factor in asset pricing, investors and researchers have developed keen interest in understanding its actual impact to enable enact policy that can favour the stock market so that they do not affect its performance.

Various studies show that the effect of macroeconomic variables on returns is present but is not significant. Therefore, this study will try to look into the significance of each macroeconomic variable. There is no general agreement on the effect of macroeconomic factors on stock market performance. For instance, Garcia and Liu (1999) established that macroeconomic volatility does not affect performance of stock market. Maku and Atanda in 2010 studied Nigeria Stock Exchange and established that 
macroeconomic factors affect stock market performance. Therefore, since elections and other political uncertainties do matter for the stock markets, politics can shape economic outcomes, affect asset prices, and change financial risk. This study will therefore explore extensively the effect of political instabilities and macroeconomic variables on stock market and on the general performance of the economy.

This study therefore sought to respond to the following questions;

- What is the effect of political events on the performance of NSE?

- What is the impact of selected macroeconomic factors on NSE performance?

\section{Objective of the Study}

The study's objective is to determine the effects of political events and macroeconomic factors on the performance of NSE in Kenya.

\section{Literature Review}

Nyang'oro (2013), using a case of Nairobi Securities Exchange, investigated foreign portfolio flows and stock market performance in Kenya. He argued that uncertainty in the market can be created by a volatile market and a significant increase in changes in exchange rate, whereas high foreign Treasury bill rate lessens the risk levels in foreign markets by making them more attractive than before. Therefore, he concludes that these variables have a negative correlation to return. Global financial market volatility can as well affect the realization of benefits from capital flows. Additionally, the international exchange rate volatility may lead to large and unfavourable swings in capital flows.

A study carried out by Robbani and Anantharaman in 2002 on the influence of political events on some stock market indices found out that political events have long-term effect on stock prices. The sample was selected from Pakistan, Sri Lanka, Indonesia, and India because political uncertainties were common in these countries. Daily data for four years was collected. Political events were considered as independent variable and is represented by a dummy variable regression coefficient. The t-test results show that political events have long term effect on the share prices.

A study was carried out by Nguthi (2013) to establish the effect of political news on companies listed at the NSE on stock market returns in Kenya during the March 2013 general elections. The study comprised of 60 trading days before and 60 trading days after the day of the election. The study sampled 19 counters and found out that 17 out of the 19 abnormal returns were not statistically significant employed market model to estimate expected returns. The study found that stock prices react to political news. Stock prices recorded increase in prices before the event date and after signifying investor 
confidence in the incoming government. The findings implicated that investors should take precautions when purchasing stocks during periods of political uncertainty.

A similar study was done by Menge et al. (2014) where they were investigating the effects of elections on stock market returns. They used data from NSE on 56 companies that covered the period before and after elections of December 2002, December 2007, and March 2013. The study findings indicated that after elections, returns were higher as compared to before elections. They recommended that investors should buy stocks after elections and sell them before elections when returns are high. Also, government should try to maintain stability after elections to avoid stock return drops.

Adam and Tweneboah (2008) used Vector Error Correlation model (VECM) and Cointegration for data of 17 years i.e. from 1991 to 2007, but on quarterly basis, to examine the impact of macroeconomic variables on stock prices in Ghana. They were examining long-run and short-run relationships on stock prices in Ghana. The results indicated a long-run relationship between macroeconomic variables and stock prices. The VECM showed that inflation and interest rate lagged have significant influence on stock market.

Attari and Safdar (2013) conducted a similar study in Pakistan and applied Exponential GARCH in examining stock market prices and macroeconomic variables. They used monthly data from December 1991 to August 2012 to explore time series analysis. They also used ADF and ARCH to check for stationarity and homoscedasticity. The result showed that macroeconomic variables have a credible influence on the prices of stocks. Furthermore, they also concluded that stock market in Pakistan was highly volatile.

A similar analysis had been done earlier in Nigeria by Maku and Atanda in 2010 using Augmented Dickey Fuller (ADF) and unit root test which examined the long-run macroeconomic determinants of stock market performance in Nigeria between the periods of 1984 and 2007. The results showed that Nigeria Stock Exchange is more responsive to changes in exchange rate, real output, inflation rate, and money supply. The variables were found to have a significant impact on Nigerian capital market performance in the long-run. They, therefore, recommended that investors should pay attention to the above factors rather than Treasury bill rate in their investment decision.

A monthly data from March 2008 to March 2012 summing up to 48 observations was used by Oriwo and Ochieng' (2012) in investigating the impact of macroeconomic variables on NSE All Share Index (NASI) and further examining whether the variations in macroeconomic variables can be used to predict future NASI. They took three variables into account i.e. commercial banks lending interest rates, 91-day Treasury bill interest rate, and 
inflation rates. They performed regressions and decided to drop lending interest rates as it was correlated with 91-Day Treasury bill interest rate. They found that a negative relationship exist between the 91-Day Treasury bill interest rate and NASI. Furthermore, they concluded that changes in macroeconomic variables have an effect on stock market performance which as well has a significant influence on foreign investor's decisions.

\section{Methodology and Estimation Theoretical Framework}

NSE performance can be computed from the regression coefficient between stock returns and macroeconomic factors (Adler \& Dumas, 1983). To establish the effect of macroeconomic factors in stock markets, the Arbitrage Pricing Theory (APT) is used. This is because APT enables specification of returns as a linear function of various factors and it is less restrictive compared to CAPM.

In APT, the return of a portfolio consists of the weighted average of expected returns, betas multiplied by the factors and the unsystematic risk.

$$
A R_{P}=\sum_{i=1}^{k} w_{i} E R_{i}+\left(\sum_{i=1}^{k} w_{i} \hat{\mathrm{a}}_{i}\right) H_{i}+\sum_{i=1}^{k} w_{i} q_{i}
$$

If a portfolio is well diversified, there is no unsystematic risk for individual security because this risk has already been diversified away.

In APT model, changes in macroeconomic factors are included as they affect performance in NSE. Thus, stock return (Rs) can be expressed as a linear factor model as shown by the equation below;

$R s=\ddot{\mathrm{a}}_{0}+\sum_{j=1}^{k} \ddot{\mathrm{a}}_{i} H_{i}+\varepsilon i$

Where Rs is the stock return, $\delta_{i}$ 's measures the sensitivities to the factors, $\mathrm{H}_{\mathrm{i}}$ are factors that affect NSE, and $\varepsilon_{\mathrm{i}}$ is the disturbance term.

\section{Empirical Model}

Multivariate regression was employed in this study. It combines all the independent variables and detects the effect of those variables on our dependent variable stock returns (in our case NSE 20 share index has been used to represent performance in NSE):

$R s$

$$
=f(I N F, E X C, M S, T B, D P O L)
$$

Where $I N F=$ inflation rates; $E X C=$ exchange rates; $T B=91$-Day Treasury bill; $M S=$ money supply; $D P O L=$ Dummy indicating major political events.

We shall extend the model in equation 3 above to estimate the macroeconomic volatility and political factors on stock market performance as follows; 


$$
\begin{gathered}
R s=\beta_{0}+\beta_{1} I N F+\beta_{2} E X C+\beta_{3} \ln M S+\beta_{4} T B+\beta_{5} D P O L \\
+\varepsilon \ldots \ldots \ldots \ldots \ldots(4)
\end{gathered}
$$

\section{Results}

Subsequenlty, we have used secondary time series data in realizing the objectives of this study. The data has been obtained from central bank monthly bulletin and capital markets authority quarterly bulletin. We have also considered monthly data from January 2000 to February 2019, making it a total of 230 observations.

\begin{tabular}{lllllll}
\multicolumn{7}{c}{ Table 1. Descriptive Statistics } \\
\hline Stats & NSE & INF & EXC & MS & TB & DPOL \\
N & 230 & 230 & 230 & 230 & 230 & 230 \\
Mean & 3537.824 & 7.628 & 83.3696 & 1345909 & 8.2237 & 0.2696 \\
Std. Dev. & 1201.961 & 4.4037 & 11.154 & 956642.4 & 3.5459 & 0.4447 \\
Min & 1043.4 & 0.2 & 61.899 & 342918 & 0.83 & 0.000 \\
Max & 5774.3 & 19.72 & 105.28 & 3344283 & 22.49 & 1.000 \\
Skewness & -0.3095 & 1.1765 & 0.5258 & 0.6558 & 0.7594 & 1.0386 \\
Kurtosis & 2.2308 & 3.6117 & 2.2600 & 2.00725 & 5.5295 & 2.0787 \\
\hline
\end{tabular}

Source: Author's Computation based on various Economic Surveys published by KNBS and Central Bank bulletins

The total number of observations considered in this study was 230 . NSE 20 share index deviates from its mean (3537.824) by 1201.961, but it ranges between 1043.4 and 5774.3. Inflation deviates from its mean (7.628) by 4.4037 , but it ranges between 0.2 and 19.72. Exchange rate deviates from its mean (83.3696) by 11.154 , but it ranges between 61.889 and 105.28. In general, the standard deviation for each variable indicates the value by which a given variable deviates from its mean. Standard deviation for the dummy variable for major political events has no meaning in this case since the dummy is either 0 or 1 .

Stock return is almost normally negatively skewed at -0.3095 and is highly peaked at 2.2308. Inflation is positively skewed and almost flat i.e. 1.1765 , and this applies to exchange rate. The amount of money in circulation M2 and 91 day treasury bill are highly peaked and positively skewed. All the independent variables are positively skewed but 91 day treasury bill seems to be normally skewed.

\section{Stationarity Test}

Unit root tests are used to detect non stationarity in all the variables. If variables are non- stationary, there is a tendency of the estimates to change over time. This characteristic leads to spurious estimates. Therefore, if variables are found to be non-stationary, successful differencing is applied until the bias is eliminated. The null hypothesis in this case is that the variable under consideration is non-stationary. 
Table 2. Test for Stationarity

\begin{tabular}{llllll}
\hline Variable & Test statistic & $\begin{array}{l}\text { Critical } \\
\text { at 1\% }\end{array}$ & $\begin{array}{l}\text { Value } \\
\text { at 5\% }\end{array}$ & $\begin{array}{l}\text { Critical valueat } \\
\mathbf{1 0 \%}\end{array}$ \\
Stock return & -3.344 & -3.997 & -3.433 & -3.133 \\
INF & -6.770 & -3.997 & -3.433 & -3.133 \\
EXC & -3.582 & -3.997 & -3.433 & -3.133 \\
InMS & -2.553 & -3.997 & -3.433 & -3.133 \\
$\boldsymbol{T B}$ & -6.906 & -3.997 & -3.433 & -3.133 \\
\hline
\end{tabular}

From Table 2, money supply and stock return are non-stationary in their native forms at 5\% significance level. This is exception of inflation and 91Day Treasury bill that are stationary at 1\%, 5\%, and 10\% significance levels. In addition, exchange rate is stationary at 5\% and $10 \%$ significance levels.

Table 3. Results after first differencing

\begin{tabular}{|c|c|c|c|c|}
\hline Variable & Test statistic & $\begin{array}{l}\text { Critical value } \\
\text { at } 1 \%\end{array}$ & $\begin{array}{l}\text { Critical value } \\
\text { at } 5 \%\end{array}$ & $\begin{array}{l}\text { Critical } \\
\text { valueat } 10 \%\end{array}$ \\
\hline Dstock return & -12.703 & -3.999 & -3.433 & -3.133 \\
\hline DlnMS & -13.848 & -3.999 & -3.433 & -3.133 \\
\hline
\end{tabular}

From Table 3, the non-stationary variables become stationary after first differencing. Stock return and money supply becomes stationary at $1 \%, 5 \%$, and $10 \%$ significance level.

\section{Correlation Matrix}

Table 4. Correlation matrix using pearson product moment at 5\%

\begin{tabular}{lcrrrrr}
\hline Variables & NSE & INF & EXC & $\operatorname{lnMS}$ & TB & DPOL \\
NSE & 1.0000 & & & & & \\
INF & 0.0555 & 1.0000 & & & & \\
EXC & 0.0106 & -0.0661 & 1.0000 & & & \\
lnMS & 0.5183 & -0.0091 & 0.8011 & 1.0000 & & \\
TB & -0.1546 & 0.1254 & 0.2059 & 0.0894 & 1.0000 & \\
DPOL & -0.0208 & -0.1894 & -0.0328 & -0.0293 & -0.0133 & 1.0000 \\
\hline
\end{tabular}

From Table 5, we observe the relationship existing between various variables used by this study. There is a strong positive relationship between NSE 20 share index and money supply. Treasury bill shows that there exists a negative correlation with NSE 20 share index. Inflation and exchange rate show a positive relationship respectively with NSE 20 share index. Inflation has a negative association with exchange rate, money supply and political events, and a positive association with 91 Day Treasury bill. Exchange rate has a strong positive relationship with money supply and 91 Day Treasury bill. Dummy variable for political event has a negative relationship with exchange 
rate. Money supply shows a positive relationship with TB and a negative relationship with political event. Finally, Treasury bill shows a negative correlation with dummy for political event. However, there is no causality shown in the table.

\section{Multicollinearity}

To test for multicollinearity, the Variance Inflation Factors (VIF) was examined. For VIF test values greater than 10 and $1 /$ VIF values less than 0.10, multicollinearity is deemed to be present (Nachtscheim et al., 2004). In the results below, multicollinearity is absent.

Table 5. Variance Inflation Factors

\begin{tabular}{lll}
\hline Variable & VIF & $1 /$ VIF \\
EXC & 3.00 & 0.333759 \\
dlnMS & 2.86 & 0.349209 \\
TB & 1.09 & 0.919061 \\
INF & 1.07 & 0.930798 \\
DPOL & 1.04 & 0.961498 \\
Mean VIF & 1.81 & \\
\hline
\end{tabular}

\section{Diagnostic Tests}

\section{Testing for Serial Correlation}

Breusch-Godfrey test was used in testing for serial correlation. The test involves a determination of lag length which was obtained by the Akaike's Information Criterion (AIC). The test results revealed that there is no autocorrelation since the p-value which is 0.0000 is less than 0.05 . Thus we reject the null hypothesis that there is no autocorrelation.

Table 6. Breusch-Godfrey LM test for autocorrelation

\begin{tabular}{llcl}
\hline Lags $(\mathrm{p})$ & Chi2 & Degrees of freedom & Prob> chi2 \\
1 & 140.102 & 1 & 0.0000 \\
\hline
\end{tabular}

H0: no serial correlation

\section{Homoscedasticity}

Using Breusch-Pagan test, results reveal that the variances of the random error terms are not constant across observations since the p-value is less than 0.05 implying that the error terms are homoscedastic leading to the rejection of the null hypothesis of constant variance. As a remedy to this bias, robust standard errors will be used.

Table 7. Breusch-Pagan test

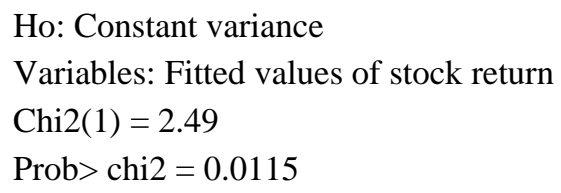




\section{Normality}

The Skewness-Kurtosis tests for normality were applied in testing for normal distribution for every variable. The table below shows the test for normal distribution using skewness and kurtosis. The joint p-value for all the variables shows that we accept the null hypothesis that their distribution is the same. On the basis of skewness, we reject the null hypothesis that skewness of the distribution inflation and 91-day treasury bill is different from the skewness of the distribution. On the basis of kurtosis, all variables are platykurtic since they are less than 3 .

Table 8. Skewness-Kurtosis tests

\begin{tabular}{lllll}
\hline Variable & Pr (Skewness) & Pr (Kurtosis) & Chi2(2) & Prob>Chi2 \\
Stock return & 0.0532 & 0.0002 & 15.01 & 0.0006 \\
INF & 0.0000 & 0.0751 & 31.77 & 0.0000 \\
EXC & 0.0015 & 0.0005 & 18.13 & 0.0001 \\
TB & 0.0000 & 0.0000 & 29.12 & 0.0000 \\
dlnMS & 0.1333 & 0.0000 & 19.31 & 0.0001 \\
DPOL & 0.0000 & 0.0000 & 45.11 & 0.0000 \\
\hline
\end{tabular}

\section{Regression Results}

Since there is stationary variables and non-stationary which become stationary after first differencing, we adopted ARDL Error Correction model. Table 9. ARDL Error Correction Model regression results

\begin{tabular}{|c|c|c|c|c|c|c|}
\hline \multicolumn{2}{|c|}{ Log likelihood $=-1635.2065$} & \multicolumn{5}{|c|}{$\begin{array}{l}\text { Number of obs }=224 \\
\text { R-squared }=0.6224 \\
\text { Adj R-squared = 0.3981 } \\
\text { MSE = 366.4733 }\end{array}$} \\
\hline D.Stock return & Coef. & Std. Err. & $\mathbf{t}$ & $P>|t|$ & {$[95 \%$ Conf } & terval] \\
\hline $\begin{array}{l}\text { ADJ } \\
\text { Stock return }\end{array}$ & & & & & & \\
\hline L1 & -0.0789 & 0.0354 & 2.23 & $\mathbf{0 . 0 2 7}$ & -0.148775 & -0.00908 \\
\hline $\begin{array}{l}\text { dlnMS } \\
\text { EXC } \\
\text { INF } \\
\text { TB } \\
\text { DPOL }\end{array}$ & $\begin{array}{r}0.00229 \\
-\mathbf{0 . 0 0 2 6 9} \\
0.07509 \\
0.00291 \\
-\mathbf{0 . 0 0 8 0 9}\end{array}$ & $\begin{array}{l}0.00075 \\
67.0479 \\
90.5362 \\
161.14 \\
904.8\end{array}$ & $\begin{array}{l}3.04 \\
-2.87 \\
-0.83 \\
-1.80 \\
1.23\end{array}$ & $\begin{array}{l}0.003 \\
0.005 \\
0.408 \\
0.073 \\
0.048\end{array}$ & $\begin{array}{l}\quad 0.00080 \\
-324.43 \\
-253.55 \\
-608.44 \\
-666.65\end{array}$ & $\begin{array}{l}0.00377 \\
-60.109 \\
103.36 \\
26.819 \\
2900.3\end{array}$ \\
\hline $\begin{array}{l}\text { SR } \\
\text { Stock return }\end{array}$ & & & & & & \\
\hline $\begin{array}{l}\text { LD. } \\
\text { L2D. } \\
\text { EXC }\end{array}$ & $\begin{array}{l}-0.22468 \\
-0.32976\end{array}$ & $\begin{array}{l}0.0568 \\
0.0552\end{array}$ & $\begin{array}{l}-3.95 \\
-5.96\end{array}$ & $\begin{array}{l}0.000 \\
0.000\end{array}$ & $\begin{array}{l}-0.33667 \\
-0.43872\end{array}$ & $\begin{array}{l}-0.11269 \\
-0.22079\end{array}$ \\
\hline $\begin{array}{c}\text { D1. } \\
\text { cons }\end{array}$ & $\begin{array}{l}-0.46839 \\
1.5224\end{array}$ & $\begin{array}{l}8.9833 \\
608.00\end{array}$ & $\begin{array}{l}-5.21 \\
2.50\end{array}$ & $\begin{array}{l}\text { 0.000 } \\
0.013\end{array}$ & $\begin{array}{l}-64.546 \\
323.94\end{array}$ & $\begin{array}{l}-29.132 \\
2720.8\end{array}$ \\
\hline
\end{tabular}


From the above table, the linear regression model below can be deduced. The independent variables are exponentially calculated as the dependent variable is in log form.

$\mathrm{Rs}=1.5224+0.07509 \mathrm{INF}-0.00269 \mathrm{EXC}+0.002291 \mathrm{nMS}+0.00291 \mathrm{~TB}-$ $0.00809 \mathrm{DPOL}$

\section{Interpretation of the Results}

The coefficient for inflation is positive but statistically insignificant since the $\mathrm{p}$-value is more than 0.05 level $(\mathrm{p}=0.408)$. Holding all other factors constant, the stock return will increase by $7.5 \%$ when inflation increases by $1 \%$. The coefficient is positive which would indicate that the higher the inflation rate, the higher the stock returns which is contrary to what we would expect. These results thus contradicts other findings of other researchers such as the study of Nyang'oro (2013).

The coefficient of exchange rate is negative and statistically significant since the $\mathrm{p}$-value is less than $0.05(\mathrm{p}=0.005)$. When all other factors are held constant, the stock return will decrease by $0.229 \%$ when exchange rate increases by $1 \%$. When the currency depreciates in value, it reduces the performance of NSE as per our results. Our results is consistent with the outcome of other researchers like Osoro and Ogeto (2013) who concluded that currency depreciation reduces stock returns.

The coefficient of money supply and 91 Day Treasury bill is positive and is statistically significant with a p-value of 0.003 and 0.073 respectively. Increase in money supply in an economy implies high inflation. This improves the stock return as investors invest in stocks. High inflation increases cash inflow into a country. The study is in agreement with early studies like Ogiji (2013) and Patel (2012) but contradicts what Oriwo and Ochieng (2012) found. They stated that increase in 91 Day Treasury bill means that it becomes more attractive to invest in them as compared to investing on common shares at NSE and, as a result, there is a decline in the stock market activity leading to decreased performance.

The coefficient of the dummy variable politics shows that the stock return decreases by 0.00809 units when political uncertainties exist within a country. The coefficient of the dummy variable for political events is negative and statistically significant at $5 \%$ level of confidence ( $p$-value $=0.048$ ). This conforms to the economic theory that political instability scares investors away from investing. Menge et al. (2014) found that during election periods, NSE performance rises before the election day but declines after the election day as the fear of the change in regime may affect the returns.

The results above indicate that regression did well in regard to the goodness of fit and also overall significance with an $\mathrm{R}^{2}$ of $62.24 \%$. This implies that $62.24 \%$ of the variation in the independent variable stock return 
has been explained by the explanatory variables. This leaves $37.76 \%$ unexplained by the model.

\section{Conclusion}

From the study, it has been found out that some of the macroeconomic factors have an effect on the performance of NSE as well as political occurrences in a country. In this situation, some causal relationships among variables was established for the data used from January 2000 to February 2019.

Information disclosure has an effect on how investors invest and which will in turn affect NSE performance. There may be an effect on the general performance of the financial sector if the stock market performs poorly. This may consequently affect the general economy.

From the findings above, it can be generalized that the government should be keen on frequent changes of various macroeconomic variables to be able to monitor the economic activities in an economy including capital market. The real market depends on all the variables discussed in this paper. Therefore, the study recommended that Central Bank should adopt better monetary policy measures to control the exchange rate and 91 Day Treasury bill because they are vital in determining stock market performance.

Performance of stock market is an indicator to the foreign investors on the stability of the stock market. It is therefore recommended that good measures should be put in place for example investor friendly policies to promote the stock market activities, thus resulting to better stock market performance. Capital Market Authority should also keep a closer check on how the stock market functions, create and boost investor confidence, and introduce new products into the stock market.

In developing the Kenyan stock market so that it remains competitive with world leading stock markets, the government needs to place emphasis on the removal of bottlenecks that may hinder the development of the NSE. This may include regulatory barriers which actually act as disincentives to investment in securities. In order to safeguard shareholders interests, the CMA should revise any sharp practices by market operators. For instance, the 5 percent tax that was to be imposed is a disincentive to investors.

Investor's confidence is important in any market operations. Potential investors particularly may be reluctant to invest in securities when they cannot give credence especially when some firms fall and close down. Investor compensation fund need to be established to assure that only credible firms are licensed to operate. This may boost investor confidence such that investors can get compensated in case of a fall. 


\section{References:}

1. Adler, M. and Dumas, B. (1983). International portfolio choice and corporation finance: A synthesis. The Journal of Finance, 38(3), 925984.

2. Alshogeathri, M.A.M. (2011). Macroeconomic determinants of the stock market movements: empirical evidence from Saudi stock market. Retrieved from http:/krex.k-state.edu/dspace/handle/2097/11989

3. Attari, M.I. and Safdar, L. (2013). The relationship between macroeconomic volatility and the stock market volatility: Empirical evidence from Pakistan. Pakistan Journal of Commerce and Social Sciences, 7(2), 309-320.

4. Capital Markets Authority (various issues). Quarterly Statistical Bulletin, Nairobi: Author.

5. Central Bank of Kenya (various issues). Monthly economic reviews, Nairobi: Author.

6. Chuang, C.-C. and Wang, Y.-H. (2009). Developed stock market reaction to political change: A panel data analysis, Graduate Institute of Management Sciences, Tamkang University, Taiwan.

7. Fama, E. (1970). Efficient capital markets: a review of theory and empirical work. Journal of Finance, 25, 383-427.

8. Gujarati, D.N. (2004). Basic Econometrics. Fourth edition, McGrawHill, Book companies, New York.

9. Garcia, V. F. and Liu, L. (1999). Macroeconomic determinants of stock. Journal of Applied Economics, 2(1), 29-59.

10. Junkin, K. (2012). Macroeconomic determinants of stock market behaviour in South Africa. Rhodes University. Retrived from http://eprints.ru.ac.za/3658/

11. Kemboi, J.K. and Tarus, D.K. (2012). Macroeconomic determinants of stock market development in emerging markets: Evidence from Kenya. Research Journal of Finance and Accounting, 3(5), 57-68

12. Khan, M., Saif, N. and Rehman, S. (2013). Stock market reaction to political events (Evidence from Pakistan). Journal of Economics and Sustainable Development, 2(1), 165-174

13. Koech,O.K. and Rotich, G. (2013). The effect of the 2008 global financial crisis on the performance of stock indices at the Nairobi Securities Exchange. International Journal of Innovative Research and Development, 2(5), 1099-1118

14. Levine, R. (1997). Financial development and economic growth. Journal of Economic Literature, 35(2), 688-726.

15. Maku, O.E. and Atanda, A.A. (2010). Determinants of stock market performance in Nigeria: Long-run analysis. Journal of Management and Organisational Behaviour, 1(3) 
16. Malik, S., Hussain, S. and Ahmed, S. (2009). Impact of political event on trading volume and stock return: The case of KSE. International Review of Business Research papers, 5(4), 354-364.

17. Menge, R.N., Mwangi, M. and Kimani, J.G. (2014). Effects of elections on stock market returns at the NSE. Prime Journal of Social Science, 3(6), 26-34.

18. Mohammad, D.S., Hussain, A. and Ali, A. (2009). Impact of macroeconomic variables on stock prices: Empirical evidence in case of Karachi Stock Exchange. European Journal of Scientific , 38(1), 96103

19. Mwega, F.M. (2010). Global financial crisis discussion series paper: Kenya phase 2. Overseas Development Institute London, 17(2), 6-8

20. Nachtscheim, C.J., Neter, J. and Kutner, M.H. (2004). Applied Linear Regression Models. $4^{\text {th }}$ edition, McGraw-Hill Irwin, Chicago.

21. Nguthi, P.N. (2013). The effect of political news on stock market returns in Kenya: The case of March 2013 general elections. Masters research paper, University of Nairobi.

22. Nyang`oro, O. (2013). Foreign portfolio flows and stock market performance in Kenya: Case of Nairobi Securities Exchange. A presentation made at the CSAE conference on Economic Development in Africa.

23. Olweny, T. and Kimani, D. (2011). Stock market performance and economic growth: Empirical evidence from Kenya using causality test approach. Advances in Economics and Applied Economics, 1(3), 153196.

24. Oriwo, A.E. and Ochieng', D.E. (2012). The relationship between macroeconomic variables and stock market performance in Kenya. DBA Africa Management Review, 3(1), 38-49.

25. Osoro, C. and Ogeto, W. (2013). Macroeconomic fluctuations effects on the financial performance of listed manufacturing firms in Kenya. The International Journal of Sciences, 21(1), 26-34.

26. Patel, S. (2012). The effect of macroeconomic determinants on the performance of the Indian stock market. NMIMS Management Review, 22, 117-127.

27. Robbani and Anantharaman (2002). An econometric analysis of stock market reaction to political events in emerging markets, second annual ABIT Conference, May 2-4, 2002, Pittsburgh, Pennsylvania

28. Srivastava, A. (2010). Relevance of macroeconomic factors for the Indian stock market. 37(3).

29. Wawire, N., Kirui, E. and Onono, P. (2014). Macroeconomic variables, volatility and stock market returns: A case of Nairobi 
Securities Exchange, Kenya. International Journal of Economics and Finance, 6(8), 214-228

30. Were, M. and Tiriongo, S. (2012). Central Bank's response to economic crises from a developing African economy perspective: Lessons from Kenya's experience.

31. Yartey, C. A. and Adjasi, C. K. (2007). Stock market development in sub-Saharan Africa: critical issues and challenges (Working paper No. 7). International Monetary Fund. 